https://doi.org/10.46344/JBINO.2021.v10i2b.12

\title{
PHYTOCHEMICAL AND PROXIMATE ANALYSES OF DIFFERENT PARTS OF AZADIRACHTA INDICA A. JUSS
}

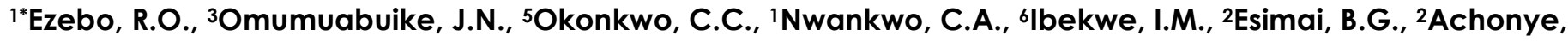 \\ C.C., 4 llouno, E.E., 7Obienyem, J.N. and Iffeanyi, C.F.
}

\begin{abstract}
'Department of Botany Faculty of Bioscience, Nnamdi Azikiwe University, P.M.B. 5025, Awka, Anambra State, Nigeria. 'Department of Animal Science and Technology, Nnamdi Azikiwe University, P.M.B. 5025, Awka, Anambra State, Nigeria. 2Department of Science Laboratory Technology, Anambra State Polytechnic, P.M.B. 002, Mgbakwu, Anambra State, Nigeria. 3Department of Animal Science, Faculty of Agriculture, Chukwuemeka Odumegwu Ojukwu University, Igbariam Campus, Anambra State, Nigeria.

${ }^{4}$ Department of Agricultural Technology, Anambra State Polytechnic, P.M.B. 002, Mgbakwu, Anambra State, Nigeria.

${ }^{5}$ Department of Home and Rural Economics, Anambra State Polytechnic, P.M.B. 002, Mgbakwu, Anambra State, Nigeria.

${ }^{6}$ Department of Nutrition and Dietetics, Anambra State Polytechnic, P.M.B. 002, Mgbakwu, Anambra State, Nigeria.
\end{abstract} 7Department of Animal Health and Production Technology, Anambra State Polytechnic, P.M.B. 002, Mgbakwu, Anambra State, Nigeria.

Email : esau_056@yahoo.com

\section{ABSTRACT}

This study was conducted to assess the phytochemical and proximate contents of different parts of Azadirachta indica. The dried and powdered fruit pulp, seed, leaf, stem, stem bark, root and root bark of $A$. indica were subjected to various sample preparation stages using standard laboratory procedures for determination of phytochemical and proximate composition in the test plant parts. Analysis of Variance (ANOVA) was employed to test for significance. Means were separated using Duncan's New Multiple Range Test (DNMRT). The results of the study revealed that there were marked differences $(P<0.05)$ in the phytochemical and proximate contents of the fruit pulp, seed, leaf, stem, stem bark, root and root bark of A. indica. Alkaloid was the highest phytochemical compound in the leaf of the test plant. Alkaloid contents of the leaf and root bark showed the highest and equal values (3.42 23.45$)$ respectively, while steroid showed the lowest content in fruit pulp $(0.15 \pm 0.17)$. Carbohydrate content of the fruit pulp showed the highest value (65.52 \pm 66.13), while the least was fat content of the root $(0.42 \pm 0.45)$. This study suggests that the phytochemical values and nutritional components of fruit pulp, seed, leaf, stem, stem bark, root and root bark of $A$. indica, could be utilized as a good source of nutrient supplement, as well as source of useful pharmaceutical products.

Keywords: Phytochemical, Proximate, Analysis, Parts, Azadirachta indica 


\section{Introduction}

Nature has been a source of medicinal agents for thousands of years and an impressive number of modern drugs have been isolated from natural sources. The use of herbs in the treatment of ailments in Africa is an age long practice. The decreasing efficacy of synthetic drugs, cost, accessibility and increasing contradiction of their usage makes the usage of natural drugs tropical. There is growing awareness by scientific and medicinal communities of the importance of medicinal plants in the health care system of many developing countries (Ame et al., 1995).

Traditionally, it is believed that natural products are safe (Said et al., 2005). This assumption to a large extent has influenced the indiscriminate use of these formulations by many particularly among rural populace (Mbaka et al., 2010). The safety of herbal medicine is of particular importance because majority of these products is self-prescribed and it is used to treat minor and often chronic conditions. Man's continuous reliance on herbs for therapeutic and nutritional benefits cannot be overemphasized. The ethnomedicinal and nutritional uses of wild plants are as old as men as they are sources of food, security and income generation (Akubugwo et al., 2007). Some of the most potent drugs in Western medicine are derived from plants, yet they are obtained from only 90 species of estimate 250,000 plant species (Dutta, 2001). Traditional societies have over the years employed medicinal plants in ethno-medicine for the treatment of various diseases without scientific knowledge of the physiologically active ingredients called phytochemicals which were responsible for the plants medicinal and pharmacological potentials (Aja et al., 2010).

Azadirachta indica (A. Juss), a member of the mahogany family Meliaceae (commonly called neem plant) has one of the most promising medicinal properties having a wide spectrum of biological activity. Neem is a large tree growing about $25 \mathrm{~m}$ in height with semistraight to straight trunk, $3 \mathrm{~m}$ in girth and spreading branches forming a broad crown. It starts giving fruits after 3-5 years and the plant is reported to live up to two centuries (Ogbuewu et al., 2011). Each and every part of neem tree has a wide range of pharmacological properties especially as antibacterial, antifungal, antiulcer, antifeedant, repellant, pesticide, inhibitor and sterilant (Mishra, 2013).

Earlier studies have shown that neem contains active substances in almost every parts i.e. seeds, leaves, roots, bark, trunk and branches and have multiple medicinal properties ( Almas and Ansallafi, 1995). Aqueous extract of neem leaf has a good therapeutic potential like an anti-hyperglycemic agent ( Bajaj and Srinivasan, 1999). Neem extract has less anti-flammatory effect than that produced by dexamethasone. Neem leaves have antibacterial properties and could be used in traditional medicine to treat infectious conditions especially those involving eye and ear (El-Mahmood et al., 2010). The aim of this study is to assess the nutritive and phytochemical constituents present in different parts of Azadirachta indica.

\section{Materials and Methods \\ Source of Materials}

Fresh samples of the leaves, fruit, stem, stem bark, root and root bark were collected from Botany garden at Nnamdi 
Azikiwe University Awka, Anambra State. They were identified by a plant taxonomist, Prof. C.U. Okeke in the Department of Botany.

\section{Preparation of Plant Samples}

Fresh samples were washed and oven dried at $65^{\circ} \mathrm{C}$ for five days. The dried samples were separately ground with metal hand grinder to fine powder. The dried powdered samples were used for the analysis.

\section{Qualitative Determination of Phytochemicals in Azadirachta indica}

Qualitative tests were conducted to evaluate the presence or absence of phytochemical of interest. It was conducted using standard methods described below.

\section{Alkaloid Determination}

The presence of alkaloid in the samples were investigated using Meyer's colourimetirc method described by Harborne (1973). Ethanolic extract of the samples were obtained by shaking $2 \mathrm{~g}$ of the samples in $20 \mathrm{ml}$ of ethanol for $30 \mathrm{mins}$ before filtrating over the funnel using Whatman filter paper in $100 \mathrm{ml}$ beaker. $2.5 \mathrm{ml}$ of each filtrate was taken and poured in the test tube labelled A, B, C and $D$, placed in a test tube rack. Few drops of Meyer's reagent were added to each of the test tube respectively. Formation of orange precipitate/colour shows the presence of alkaloid.

\section{Saponin Determination}

The froth test and emulsion test described by Harborne (1973) were used to determine the presence of saponin. $5 \mathrm{ml}$ of distilled water was used to dissolve $1 \mathrm{~g}$ of powdered samples in $250 \mathrm{ml}$ conical flask. Each of them was shaken and placed in water bath for 5 mins. They were filtered hot over the funnel using Whatman filter paper in $100 \mathrm{ml}$ beaker.
$2.5 \mathrm{ml}$ of each cooled filtrate was poured into the test tube labelled A, B, C and D, and placed in a test tube rack. $10 \mathrm{ml}$ of distilled water was used to dilute each of the tube respectively.

\section{Froth Test}

Each of the flask was shaken vigorously for few minutes and observed. A stable froth (foam) upon standing indicates the presence of saponin.

\section{Emulsion Test}

Two drops of olive oil was added to the four test tubes respectively and shaken vigorously. The formation of emulsion indicates the presence of saponin.

\section{Tannin Determination}

The presence of tannins was determined using the Harborne (1973) method. $1 \mathrm{~g}$ of powdered samples were boiled with $5 \mathrm{ml}$ of distilled water in a water bath for 5 minutes. They were filtered hot with Whatman filter paper folded over a funnel in $100 \mathrm{ml}$ beakers. Four test tubes labelled A, B, C and D, was positioned in a test tube rack. $1 \mathrm{ml}$ of the cooled filtrates was added to each test tube accordingly. $10 \mathrm{ml}$ of ferric chloride was added to each of the test tube and observed. A greenish brown precipitate was observed which indicates the presence of tannin.

\section{Flavonoid Determination}

The presence of flavonoid in the samples was determined using the Harborne (1973), Sofowora (1993) methods. Ig of powdered samples were dissolved with $10 \mathrm{ml}$ of distilled water in $250 \mathrm{ml}$ conical flask, shaken and placed in water bath for 5 mins. They were filtered hot using Whatman filter paper folded over the funnel in $100 \mathrm{ml}$ beaker. The filtrates were allowed to cool. Two drops of $20 \% \mathrm{NaOH}$ was added to $1 \mathrm{ml}$ of each of the filtrates in a test tubes labelled A, B, C and D. A 
yellow amber colour was observed in tubes $A$ and $D$, light yellow in $B$ and $C$. To each of the test tube was also added two drops of one normal sulphuric acid and observed. No colour change was observed in all the samples after addition of two drops of sulphuric acid. It implied that flavonoid is present in the plant due to formation of colourless solution.

\section{Cardiac Glycoside Determination}

$5 \mathrm{ml}$ of each of the aqueous extracts was taken using $5 \mathrm{ml}$ syringe into the test tubes labelled A, B, C and D. $2 \mathrm{ml}$ of glacial acetic acid was added to each of the tube. One drop of ferric chloride was also added respectively. $1 \mathrm{ml}$ of concentrated sulphuric acid was added to the four tubes and observed for brownish or greenish precipitate. Flask $A, C$ and D was found to contain cardiac glycoside as the colour being evident while flask $B$ has clear solution.

\section{Phlobatanin Determination}

$5 \mathrm{ml}$ of aqueous extracts of each of the samples was taken with $5 \mathrm{ml}$ syringe and added to four test tubes labelled A, B, C and D. $5 \mathrm{ml}$ of $1 \% \mathrm{HCL}$ was added to each of the tube and placed in a conical flask and boiled in a water bath for 5 mins. Red precipitate was observed in flask $D$ only which indicates the presence of phlobatanin.

\section{Terpenoid Determination}

$5 \mathrm{ml}$ of aqueous extracts from each of the samples was poured into the test tube labelled A, B, C and D. $2 \mathrm{ml}$ of chloroform was added to each of the test tube. $1 \mathrm{ml}$ of concentrated sulphuric acid was also added to each of the flask to form a layer. A reddish brown precipitate at the interface indicates the presence of terpenoid.

\section{Reducing Sugar Determination}

To $1 \mathrm{~g}$ of powdered samples were added $15 \mathrm{ml}$ of distilled water in $250 \mathrm{ml}$ conical flask. It was shaken and placed in a water bath for 5 minutes. The solution was filtered hot in Whatman filter paper and folded over a funnel in $100 \mathrm{ml}$ beaker. $1 \mathrm{ml}$ of the filtrates was taken from each of the beaker into a test tube labelled A, B, C and $D$, and positioned in a test tube rack. To each of the test tube was added 3 drops of $20 \% \mathrm{NaOH}$ and tested with red litmus paper which turned blue. $1 \mathrm{ml}$ of Benedict solution was added to each of the test tube respectively, boiled in a water bath for 5 mins and observed for brick red precipitate.

\section{Carotenoid Determination}

To $1 \mathrm{~g}$ of powdered samples was added $10 \mathrm{ml}$ of chloroform in a conical flask and shaken. They were filtered with Whatman filter paper over a funnel in $100 \mathrm{ml}$ beaker. To $1 \mathrm{ml}$ of the filtrates were added three drops of $85 \%$ sulphuric acid and observed for blue colouration. No colour change was observed in the four test tubes.

\section{Quantitative \\ Determination \\ of}

\section{Phytochemicals in A. indica}

\section{Determination of Alkaloid}

$2 \mathrm{~g}$ of each sample was analysed in accordance with the alkaline precipitation gravimetric method (Harborne, 1973). The weighed samples were soaked in $100 \mathrm{ml}$ of $10 \%$ acetic acid solution in ethanol and allowed to stand for 4 hours at room temperature before filtering using Whatman filter paper. The filtrates were reduced to a quarter of their original volume by evaporation over a steam bath. Alkaloids in the extracts were precipitated by drop wise addition of concentrated $\mathrm{NH}_{4} \mathrm{OH}$ solution until full turbidity was obtained. The precipitate was recovered by filtration using weighed filter papers and then washed with 1\% 
$\mathrm{NH}_{4} \mathrm{OH}$ solution, dried in the oven at $100^{\circ} \mathrm{C}$ for an hour. They were cooled in desiccator and reweighed. By difference, the weight of alkaloids present in the samples were determined and expressed as percentage for the samples and analysed using the formula;

$\%$ Alkaloid $=\mathrm{W} 2-\mathrm{W} 1 \times 100 /$ Weight of sample

Where;

$\mathrm{W} 1=$ weight of empty filter paper

W2 $=$ weight of paper + alkaloid precipitate

\section{Determination of Saponin}

Saponin content of the samples were determined by double solvent extraction gravimetric method (Harborne, 1973). $2 \mathrm{~g}$ of the powdered samples were mixed with $50 \mathrm{ml}$ of $20 \%$ aqueous ethanol solution. The mixtures were heated with periodic agitation in water bath for 30 mins at $55^{\circ} \mathrm{C}$. They were filtered, the residues were extracted with $50 \mathrm{ml}$ of ethanol and both extracts were put together. The combined extracts were reduced to about $40 \mathrm{ml}$ at $90 \circ \mathrm{C}$ and transferred to a separating funnel where $40 \mathrm{ml}$ of diethyl ether was added and shaken vigorously. Separation was by partition during which the ether layer was discarded and the aqueous layer reserved. Reaction was carried out until the aqueous layer became clear. The saponins were extracted with $60 \mathrm{ml}$ of normal butanol. The combined extracts were washed with $5 \%$ aqueous $\mathrm{NaCl}$ solution and evaporated to dryness in a pre-weighed evaporating dish. They were dried at $60^{\circ} \mathrm{C}$ in the oven and reweighed. The saponin content was calculated as percentage of original sample as;

$\%$ Saponin $=\mathrm{W} 2-\mathrm{W} 1 \times 100 /$ Weight of sample

Where;
$W 1=$ weight of evaporating dish

W2 = weight of dish + sample

\section{Determination of Tannin}

The Follins - Dennis spectrophotometric (Pearson, 1976) was used. $2 \mathrm{~g}$ of the powdered samples were dispensed into $50 \mathrm{ml}$ of distilled water in a conical flask and shaken for 30mins in a shaker. The mixtures were filtered. $5 \mathrm{ml}$ of the filtrates were measured into $50 \mathrm{ml}$ volumetric flask and then diluted with $35 \mathrm{ml}$ of distilled water. Also, $5 \mathrm{ml}$ of standard tannic acid solution and $5 \mathrm{ml}$ of distilled water were measured with separate flasks to serve as standard and blank respectively. They were diluted with $35 \mathrm{ml}$ of distilled water separately. $1 \mathrm{ml}$ of Follins - Dennis Reagent was added to each of the flask followed by $2.5 \mathrm{ml}$ of saturated sodium carbonate solution. The content of each flask was filled to mark level with distilled water and incubated for $90 \mathrm{mins}$ at room temperature. The absorbance of the developed colour was measured at $76 \mathrm{~nm}$ wavelength with the reagent blank at zero. The tannin content was calculated as shown below;

$\%$ Tannin $=100 / \mathrm{W} \times \mathrm{AU} / \mathrm{As} \times \mathrm{VF} / \mathrm{VA} \times \mathrm{D}$ Where;

$W=$ weight of the sample analysed

$\mathrm{AU}=$ absorbance of test sample

AS = concentration of standard in $\mathrm{mg} / \mathrm{ml}$

$C=$ total volume of extract

$\mathrm{VF}=$ volume of filtrate analysed

$D=$ dilution factor (where applicable)

\section{Determination of Flavonoid}

Flavonoids determination was done using Bohamand Kocipai method. $10 \mathrm{~g}$ of the plant samples were extracted repeatedly with $100 \mathrm{ml}$ of $80 \%$ aqueous methanol in conical flask at room temperature. The whole solution was filtered using a weighed Whatman filter paper. The filtrates were transferred into crucible and 
dryness in the oven, cooled in the desiccator and weighed. The percentage flavonoid was expressed as the weight of sample analysed using the formula;

$\%$ Flavonoid $=\mathrm{W} 2-\mathrm{W} 1 \times 100 /$ Weight of sample

Where;

$\mathrm{W} 1$ = weight of empty filter paper

W2 = weight of filter paper + flavonoid precipitate

\section{Proximate Analysis}

This was carried out using mainly the method described by Association of Official Analytical Chemists (A.O.A.C, 1990). It involves the determination of protein, ash, moisture, fat and carbohydrate content.

\section{Determination of Protein}

Protein content of the sample was determined by the Kjeldahl method reported by James (1995). The total nitrogen $\left(\mathrm{N}_{2}\right)$ was determined and multiplied by the factor 6.25 to obtain the protein content. $0.5 \mathrm{~g}$ of the powdered samples were weighed into a Kjeldahl digestion flask and a table of selenium catalyst was added to it. $10 \mathrm{ml}$ of conc. $\mathrm{H}_{2} \mathrm{SO}_{4}$ was then added to the flask and digested by heating under a fume cupboard until a clear solution was obtained. It was transferred to $100 \mathrm{ml}$ volumetric flask and made up to with distilled water and $10 \mathrm{ml}$ of $45 \% \mathrm{NaOH}$ solution in a Kjeldahl distillation apparatus. The mixture was distilled and the distillate collected into $10 \mathrm{ml}$ of $4 \%$ boric acid solution containing mixed indicator-methyl red bromoressol. A total of $50 \mathrm{ml}$ distillate was collected and titrated against $0.02 \mathrm{~m} \mathrm{H}_{2} \mathrm{SO}_{4}$. The total $\mathrm{N}_{2}$ content was calculated using the relationship that $1 \mathrm{ml}$ in $\mathrm{H}_{2} \mathrm{SO}_{4}=14 \mathrm{~g} \mathrm{~N}$. Thus;
$\% \mathrm{~N} 2=100 / \mathrm{W}[\mathrm{N} \times 14 \times \mathrm{V} \dagger / 100] \mathrm{T}-\mathrm{B} / \mathrm{Va}$

Where;

$\mathrm{T}-\mathrm{B}=$ Titre (less blank)

$\mathrm{N}=$ Normality of $\mathrm{H}_{2} \mathrm{SO}_{4}=0.02 \mathrm{~m}$

$\mathrm{Vt}=$ Total digest volume $=100 \mathrm{ml}$

$\mathrm{Va}=$ volume of digested distilled $=10 \mathrm{ml}$

$\mathrm{W}=$ weight of sample analysed $=0.5 \mathrm{~g}$

The percentage of protein is thus; \% $\mathrm{N}_{2} \times 6.25$

\section{Determination of Fat}

Fat content was determined by the continuous solvent extraction method using a Soxhlex apparatus as described by Pearson (1976). An extraction flask was washed and dried in oven for 30mins and then placed in a desiccator to cool. $2 \mathrm{~g}$ of powdered samples were weighed and transferred in a rolled A4 paper, then placed in the extractor thimble. The thimble was placed into Soxhlex extractor. About three quarter of the volume of petroleum ether was poured into the extraction flask. Soxhlex was connected to the flask and condenser turned on. The heater was switched on and the temperature not exceeding boiling point of the petroleum ether was allowed to run for 3-6 hours. At the end of the extraction, the ether recovered before the thimble was removed. Finally, the oil in the flasks was dried at $100^{\circ} \mathrm{C}$ in an oven. The extracts were weighed. The difference in the weight of empty flask and the flask with the oil gave the oil content of the sample.

\section{Determination of Crude Fibre}

The crude fibre was determined by the Weende method described by both Pearson (1976) and James (1995). $2 \mathrm{~g}$ of samples were weighed and defatted (during fat analysis) and the defatted samples were boiled in $200 \mathrm{ml}$ of $1.25 \%$ of $\mathrm{H}_{2} \mathrm{SO}_{4}$ solution in a water bath. Boiling was done for 30mins after which the mixture 
was washed with distilled water and filtered using filter paper. The samples were transferred back to the boiling flask and $200 \mathrm{ml}$ of $1.25 \mathrm{NaOH}$ solution was added. The mixture was again boiled for 30mins, washed with distilled water and drained. After draining, they were transferred to a weighed crucible and dried in the oven at $105^{\circ} \mathrm{C}$ to a constant weight. The weight was recorded and the samples were taken to a furnace and burnt to ashes. Also, after cooling in a desiccator, the crucible with its ash content was reweighed. The weight of fibre was determined and expressed as a percentage of the weight of sample and analysed thus;

$\%$ Crude Fibre $=\mathrm{W} 2-\mathrm{W} 1 \times 100 /$ Weight of sample

Where;

$\mathrm{W}_{1}=$ weight of crucible + ash

W2 = weight of crucible + sample after drying to constant weight.

\section{Determination of Moisture}

The moisture content of the samples was determined by a sample method described by Pearson (1976) and James (1995). $2 \mathrm{~g}$ of samples which was sliced up was placed in a pre-weighed moisture can. Then they were placed in an oven to dry at $65^{\circ} \mathrm{C}$ till brittle. The moisture can with the dried samples were transferred to desiccator to cool to room temperature before being weighed again. The moisture content of the samples was determined by the formula;

$\%$ Moisture $=\mathrm{W} 2-\mathrm{W} 1 \times 100 /$ Weight of sample

Where;

$\mathrm{W} 1$ = weight of moisture can with sample before drying

W2 = weight of moisture can with dried sample

\section{Determination of Ash}

This was done by furnace incineration gravimetric method described by James (1995). $2 \mathrm{~g}$ of powdered samples were measured into a previously weighed crucible. The samples were burnt to ash in a muffle furnace at $550^{\circ} \mathrm{C}$ and allowed to burn for 2-3 hours until the sample became grey ash. The sample in a crucible was carefully removed from the furnace (taking care not to allow air blow them away) and cooled in a desiccator and weighed. The weight of the ash obtained was calculated as a percentage of the weight of the sample analysed as shown below;

Where;

$\mathrm{W} 1$ = weight of empty crucible

W2 $=$ weight of crucible + ash

\section{Determination of Carbohydrate}

The carbohydrate content was determined by algebraic calculation of the difference as the nitrogen free extractive (NFE), a method separately described by Pearson (1976) and James (1995).

$\%$ NFE $=100-\%(a+b+c+d+e)$

Where;

a - Protein

b - Fat

c- Fibre

d-Ash

e-Moisture

\section{Statistical Analysis}

All data were analysed with Analysis of Variance (ANOVA) to test for significance. Means were separated using Duncan's New Multiple Range Test (DNMRT) at 5\% level of probability using Statistical Analysis Software package (SAS 1999).

\section{Results}


Qualitative Determination of Phytochemical Composition of Various Parts of $A$. indica

The results of the qualitative phytochemical analysis of different parts of Azadirachta indica showed the presence of alkaloid, saponin, steroid, flavonoid, tannin, hydrogen cyanide and terpenoid. Alkaloid was present in the fruit pulp, stem, stem bark and root and deeply present in the seed and root bark and very deeply present in leaf. Saponin was present in all parts. Steroid was deeply present in leaf and root bark and present in the fruit pulp, seed, root, stem and stem bark. Flavonoid was present in fruit pulp, leaf, stem, root, stem bark and root bark and deeply present in seed. Tannin was present in fruit pulp, seed, stem, stem bark, root and root bark and deeply present in leaf. Hydrogen cyanide (HCN) was deeply present in seed and leaf and present in fruit pulp, stem, stem bark, root and root bark. Terpenoid was present in all parts (Table 1).

Table 1: Photochemical present in different parts A. indica

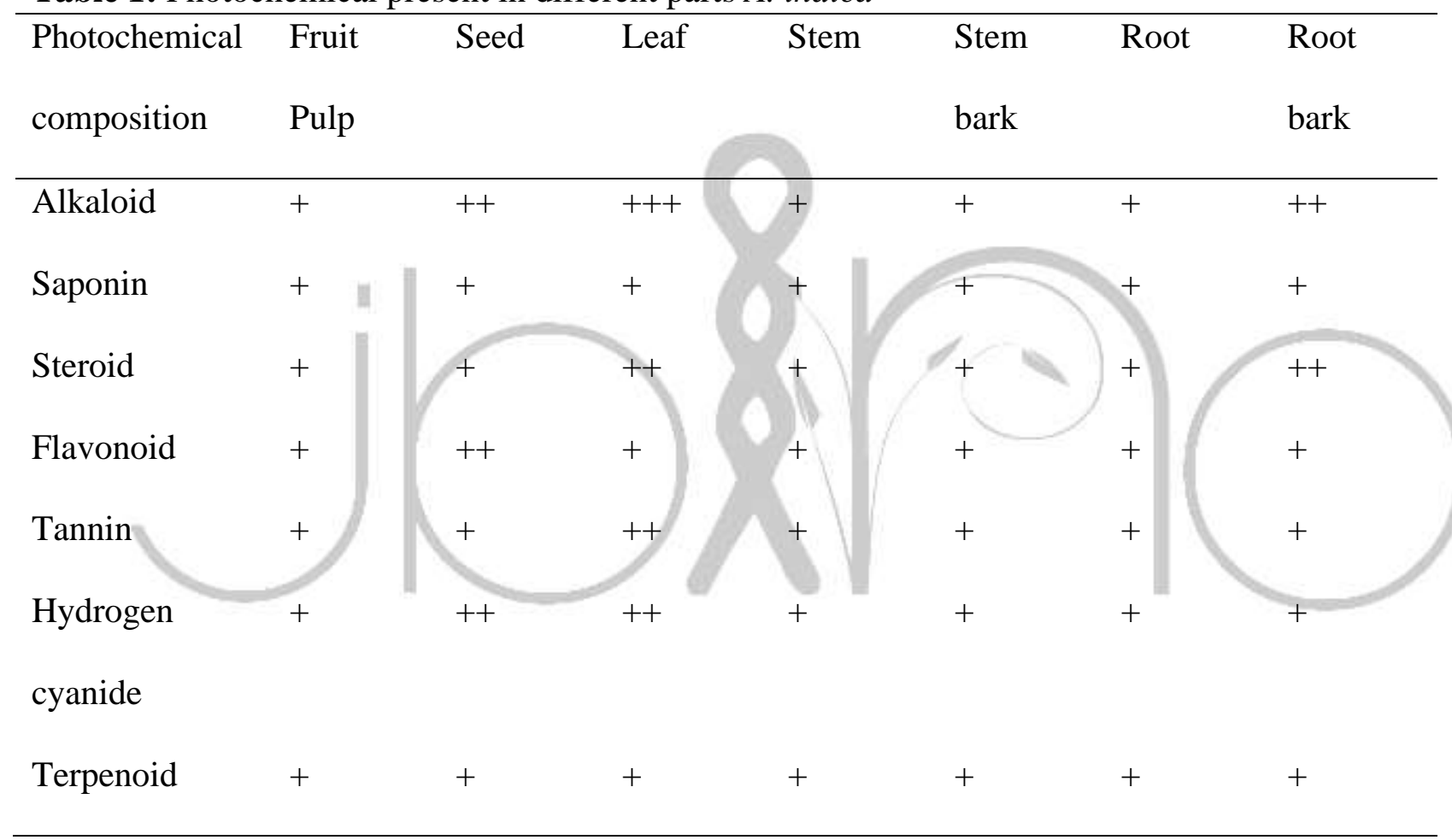

Key: + -Present, ++ -Deeply present, +++ -Very deeply present

\section{Quantitative Determination of Phytochemical Composition of Various Parts of A. indica}

Quantitative phytochemical analysis of various parts of Azadirachta indica revealed that alkaloid contents of the leaf and root bark showed the highest and equal values $(3.42 \pm 3.45)$ respectively while steroid showed the lowest content in fruit pulp $(0.15 \pm 0.17)$ (Table 2$)$. 
Table 2: Percentage phytochemical composition of different parts of A. Indica (\%)

\begin{tabular}{llllllll}
\hline Photochemical & Fruit Pulp & Seed & Leaf & Stem & Stem & Root & Root bark \\
composition & & & & & & \\
& & & & & & \\
& & & & & & \\
\hline Alkaloid & $1.65 \pm 1.68$ & $2.90 \pm 2.92$ & $3.42 \pm 3.45$ & $2.76 \pm 2.72$ & $2.90 \pm 2.95$ & $2.14 \pm 2.20$ & $3.42 \pm 3.45$ \\
Saponin & $1.34 \pm 1.36$ & $1.96 \pm 1.92$ & $1.89 \pm 1.86$ & $2.28 \pm 2.30$ & $2.54 \pm 2.60$ & $2.40 \pm 2.42$ & $2.48 \pm 2.60$ \\
Steroid & $0.15 \pm 0.17$ & $0.26 \pm 0.24$ & $0.32 \pm 0.30$ & $0.18 \pm 0.19$ & $0.24 \pm 0.26$ & $0.20 \pm 0.20$ & $0.23 \pm 0.28$ \\
Flavonoid & $1.34 \pm 1.36$ & $2.34 \pm 2.37$ & $1.43 \pm 1.48$ & $1.89 \pm 1.92$ & $2.65 \pm 2.68$ & $2.13 \pm 2.19$ & $2.75 \pm 2.80$ \\
Tannin & $1.38 \pm 1.40$ & $1.54 \pm 1.50$ & $1.78 \pm 1.82$ & $1.26 \pm 1.25$ & $1.54 \pm 1.56$ & $1.18 \pm 1.20$ & $1.63 \pm 1.65$ \\
Hydrogen & $1.48 \pm 1.50$ & $1.83 \pm 1.90$ & $3.45 \pm 3.60$ & $0.76 \pm 0.75$ & $0.74 \pm 0.76$ & $0.53 \pm 0.60$ & $0.80 \pm 0.85$ \\
cyanide & & & & & & & \\
Terpenoid & $0.60 \pm 0.63$ & $0.65 \pm 0.63$ & $0.76 \pm 0.75$ & $0.28 \pm 0.30$ & $0.45 \pm 0.48$ & $0.36 \pm 0.39$ & $0.54 \pm 0.54$
\end{tabular}

Results are in Mean \pm Std.

\section{Proximate Composition of Different Parts of $\boldsymbol{A}$. indica}

The proximate analysis of the various parts of the $A$. indica indicated that carbohydrate content of the fruit pulp recorded the highest value $(65.52 \pm 66.13)$ while the least was fat content of the root $(0.42 \pm 0.45)$ (Table 3).

Table 3: Mean proximate composition of different parts of A. indica $\%$ composition

\begin{tabular}{llllllll} 
Constituents & Fruit Pulp & Seed & Leaf & Stem & Stem bark & Root & Root bark \\
\hline Protein & $15.43 \pm 14.64$ & $16.70 \pm 16.72$ & $18.30 \pm 18.16$ & $6.83 \pm 6.90$ & $7.32 \pm 7.40$ & $7.42 \pm 7.50$ & $8.36 \pm 8.30$ \\
Fibre & $2.89 \pm 2.93$ & $3.45 \pm 3.38$ & $13.76 \pm 13.65$ & $16.30 \pm 16.45$ & $16.85 \pm 16.74$ & $7.42 \pm 7.50$ & $19.24 \pm 18.70$ \\
Ash & $3.86 \pm 3.90$ & $4.76 \pm 4.90$ & $17.45 \pm 16.80$ & $18.52 \pm 19.60$ & $20.95 \pm 19.84$ & $20.30 \pm 20.26$ & $21.76 \pm 21.80$
\end{tabular}




$\begin{array}{llllllll}\text { Moisture } & 10.54 \pm 10.60 & 10.16 \pm 10.20 & 11.45 \pm 11.42 & 9.45 \pm 9.20 & 8.95 \pm 8.90 & 8.76 \pm 8.90 & 9.30 \pm 9.24 \\ \text { Fat } & 1.76 \pm 1.80 & 4.60 \pm 5.12 & 1.58 \pm 1.53 & 0.75 \pm 0.73 & 0.65 \pm 0.68 & 0.42 \pm 0.45 & 0.48 \pm 0.50 \\ \text { Carbohydrate } & 65.52 \pm 66.13 & 60.33 \pm 59.68 & 37.46 \pm 38.54 & 48.15 \pm 47.12 & 45.28 \pm 46.44 & 55.68 \pm 55.39 & 40.86 \pm 41.46\end{array}$

Results are in Mean \pm Std.

\section{Discussion}

The result of the study revealed the presence of alkaloid, tannin, terpenoid, steroid, hydrogen cyanide and flavonoid. The result showed that alkaloid content of the leaf and root bark had the highest values $(3.42 \pm 3.45)$ respectively while the least was steroid content of the fruit pulp $(0.15 \pm 0.17)$. Alkaloids are phytochemical compounds which are widely distributed in all vascular plants ( Harborne, 1973). Alkaloids include morphine, cocaine, atropine, quinine and caffeine, most of which are used in medicine as analgesic or anaesthetic (Beckett and Stenlatic, 1988). They have potentials in management of several diseases like diabetes, Hodgkin's disease, childhood leukemia, malaria, rheumatism, laryngitis, dysmenorrhea and high blood pressure (Shibata, 2001).

Saponins are widely distributed and have been reported in over 70 plant families. They are active agent with soap-like properties (Dalziel, 1995). The search for plant saponin was stimulated by the need in source sapogenins, which can be converted to animal steroids in the laboratory, and which are to be used readily in treatment of certain diseases (Harborne, 1973). Some examples of such compounds include cortisone and the estrogenic contraceptive (Dubrosvsky,
2005). Tannins are naturally chemical constituents of plants and are known to be useful in wound healing (Trease and Evans, 1996) as astringents and antimicrobial (Lotito, 2006). Similarly, glycosides are used for treatment of heart diseases (Trease and Evans, 1996), cancer and sickle cell anaemia (Ghani, 1990) and for sanitary purpose in the body. The result also revealed the proximate nutrient composition of different parts of $A$. indica. Carbohydrate $(65.52 \pm 66.13)$ was the highest nutrient content found in the fruit pulp, while the least was fat $(0.42 \pm 0.45)$ which was found in the root. Carbohydrates are hydrolysed in the body to yield glucose which can be utilized immediately or stored as glycogen in the muscles and liver for future use (Raven et al., 1999). When carbohydrate is inadequate in the diet or during starvation, the body protein is utilized for energy (Raven et al., 1999). Fats are secondary plant products that yield more energy per gram than carbohydrates. Fats and oils help to regulate blood pressure (McDonald et al., 1998). Fibres are parts of fruits, grains and vegetables which can neither be digested nor absorbed by human system (Agarwal et al., 2001). They reduce the levels of plasma cholesterol and prevent colon cancer and cardiovascular disease 
(Davidson et al., 1976). Proteins are important in the body for the production of hormones, enzymes and blood plasma systems. They are immune boosters and can help in cell division as well as growth (Okeke and Elekwa, 2006). Ash content of a plant based food is the function of the mineral elements present (Dutta, 2001). Dietary ash has proved helpful in establishing and maintaining acidalkaline balance of the body system as well as in controlling hyperglycemic conditions (Trease and Evans, 1996).

\section{Conclusion}

This study has therefore established the fact that $A$. indica can be used as a source of useful drugs and food depending on the method of extraction and the process involved in its preparation. The findings of this study have revealed that $A$. indica possessed abundant phytochemicals and nutrient constituents in its parts which vary from one part of the plant to another.

\section{References}

Agarwal, A., Shen, H., Agarwal, S. and Rao, A.V. (2001). Lycopene content of tomato products: Its stability, bio availability and in vivo antioxidant properties. Journal of Medicinal Food, 4(1):9-15.

Aja, P.M., Okaka, A.N., Onu, P.N., Ibiam, U.S. and Urako, A.J. (2010). Phytochemical composition of Talinum triangulare (water leaf). Pakistan Journal of Nutrition, 5: 166168.

Akubugwo, I.E., Obasi, A.N. and Ginika, S.C. (2007). Nutritional potential of the leaves and seeds of black nightshade - Solanum nigrum L. Var virginicum from Afikpo, Nigeria. Pakistan Journal of Nutrition, 6: 323-326.
Almas, K. and Ansallafi, T.R. (1995). The natural toothbrush. World Health Forum, 6: 206-210.

Ame, I.O., Bakhiet, A. and Salah, E.I. (1995). Therapeutic utility constituents and toxicity of some medicinal plants. Veterinary and Human Toxicology, 37(3): 42-53.

Association of Official Analytical Chemists (1990). Official Methods of Analysis (15th ed.). Washington DC, USA. 122p.

Bajaj, S. and Srinivasan, B.P. (1999). Investigation into the anti-diabetic activity of Azadirachta indica. Indian Journal Pharmacol., 31: 138-141.

Beckett, A.A. and Stenlatic, J.B. (1988). Practical Pharmaceutical Chemistry II. Althane Press, London. 550p.

Dalziel, J.M. (1995). Useful Plants of Tropical West Africa. Crown Agents for Overseas Government, London. Pp. 362-371.

Davidson, S., Pasmore, R., Brock, J.F. and Truswell, A.S. (1976). Human Nutrition and Dietetics (6th ed.). Church Hill Livingstone, London. 342p.

Dubrosvsky, B.O. (2005). Steroids, neuroactive, steroids in Psychopathology. Progress in Neuropsychopharmacology and Biological Psychiatry, 29: 169-192.

Dutta, A.C. (2001). Botany for Degree Students (6th ed.). Oxford University Press, New Delhi. 708p.

El-Mahmood, A.M., Ogbonna, O.B. and Raji, M. (2010). The antibacterial activity of Azadirachta indica (Neem) associated with ear and eye infections. Journal of Medicinal Plant Research, 14: 1414-1421.

Ghani, A. (1990). Introduction to Pharmacognosy (2nd ed.). Oxford University Press, New York. 372p.

Harborne, J.B. (1973). Phytochemical Methods. A guide to modern technique in plant analysis. Chapman and Hall, New York. 278p. 
James, C.S. (1995). Analytical Chemistry of Foods. Chapman and Hall, New York. Pp. 10-57.

Lotito, S. B. (2006). Consumption of flavonoid rich foods and increased antioxidant capacity in humans: causes, consequences or epiphenomenon? Free Radical Biology and Medicine, 41 (12): 1727-1746.

Mbaka, G.O., Adeyemi, O.O. and Oremosu, A.A. (2010). Acute and sub chronic toxicity studies of the ethanol extract of the leaves of Sphenocentrum jollyanum (Menispermaceae). Agricultural and Biological Journal of Nutrition, 1(13): 265272.

Mc Donald, P., Edwards, R.A., Greenhalgh, J.F.D. and Morgan, C.A. (1998). Animal Nutrition (5th ed.). Longman, London. 607p.

Mishra, M., Neema, NN. And Poonam, P. (2013). Antibacterial effects of crude extracts of Azadirachta indica against Escherichia coli and Staphylococcus aureus. International Journal of Science, Environment and Technology, 2(5): 989993.

Ogbuewu, I.P. (2011). The growing importance of Neem. Research Journal of Medicinal Plant, 5(3): 230-245.

Okeke, C.U. and Elekwa, I. (2006). Proximate and preliminary phytochemical analyses of Avocado pea, Persia gratissima Gaertn. (Family Lauraceae). Nigerian Journal of Botany, 19(1): 156-162.

Pearson, D. (1976). Laboratory Technique in Food Analysis (1st ed.). Butterworth, London. 523p.

Raven. P.M., Johnson, G.B. and Maidson, W.I. (1999). Biology (2nd ed.). Mc-Graw Hill, London. 1567p.

Said, O., Khalil, K., Fulder, S. and Azaizeh, H. (2005). Ethnobotanical survey of medicinal herbs of the middle Eastern region. Journal of Ethnopharmacology, 83: $251-265$.

Shibata, S. (2001). Chemistry and Cancer Preventing Activities of Saponin and some Related Triterpenoids Compounds. Korean Medical Science Press. 430p.

Sofowora, A. (1993). Medicinal Plants and Traditional Medicine in Africa (2nd ed.). Spectrum Books Limited, Ibadan, Nigeria. 289p.

Trease, G.E. and Evans, W.C. (1996). A Text Book of Pharmacology (14th ed.). Bailliere Tindall Limited, London. 421p. 